\title{
Mechanical Properties of Polyvinyl Chloride Plastics Recycled Aggregate Concrete
}

\author{
Adel A. Al-Azzawi ${ }^{1}$, Mustafa S. Shalal ${ }^{2}$ \\ ${ }^{1,2}$ Al-Nahrain University \\ *Corresponding Author E-mail: dr_adel_azzawi@yahoo.com
}

\begin{abstract}
The concrete prepared with Polyvinyl chloride plastics (collected from doors and windows wastes) as recycled coarse aggregates and their concrete engineering properties are studied in the laboratory in this research. The concrete blends have an expected cylinder compressive strength of $28 \mathrm{MPa}$. In this research, the concrete blends contain plasticcoarse aggregate. The ratio of this aggregate to the total aggregate volume ranges from 0 to 1 . The concrete strength properties in tension and compression are greatly affected with the plastic replacement ratio. The blends density reduces with increasing replacement ratio. For low replacement ratio, the effect is practically marginal. It is not acceptable to use ACI 318 code spilt cylinder equation for plasticaggregate concrete with higher replacement ratio
\end{abstract}

Keywords: Compressive strength, Concrete, Recycled, Tensile strength, waste plastics.

\section{Introduction}

The major component of concrete blends is the aggregate which comprise $65-80 \%$ of the mix volume.The aggregate affect the properties of resulting concrete blend such as workability, strength, and durability. The use of waste or recycled materials in concrete blends can solve the problem of the large amount of waste disposal. The environmental pollution problems andaggregate scarcity in construction sites can be solved through this technique[1]. Iraq and especially, Baghdad is producing more waste each year. Over the past 40 years, the waste produced in Iraq has more than six times, from 0.5 million tons in late 1970 to about 3 million tons in 2010 around $2 \mathrm{~kg}$ of waste each day. The utilization of plastic waste materials as aggregate in concrete blends has an important applications because plastic material has enlarged toughness, fine abrasion resistance, lesser thermal conductivity and large heat capacity [2]. The rigid Polyvinyl chloride(PVC) has been used effectively in the different applications and generates huge waste material. It is important to dispose this waste material by reusing it in the concrete composition. This application may save energy and reduce the demand to primary mineral resources. Therefore, the reuse of plastic waste material in concrete is considered the best environmental alternative method to reduce the environmental pollution and safeguarding the natural resources.Sustainable concrete is a concept of use eco- friendly materials in concrete to make the structure more sustainable at less energy in its production and produces less carbon dioxide than normal concrete. Different waste materials are used as a partial replacement to cement or can be used as aggregate in sustainable concrete, so the environment isprotected from waste deposits. The green concrete was first originated in Denmark in the 1998 [3]. Elzafraney et al. (2005) [4] studied the thermal insulation due to using recycled plastics (polyvinyl chloride (PVC) as a partial replacement for natural coarse aggregates in structures for construction and design purposes.Jasim (2009) [5] replaced partially the natural coarse aggregate using plastic hollow aggregate (PHA) with different shape. This PHA aggregate can be utilized in nonstructural Concrete units. Mathew et al (2013) [6] investigated the utilization of recycled plastics in concrete mixes as coarse aggregate. The physical plastic aggregate properties of density, specific gravity, and crushing value of plastics were measured.Khalaf (2015) [7] used waste plastic aggregate as substitution of natural aggregate to produce sustainable concrete. The mixture content percentage were $(1: 1.2: 1.8)$ (cement: sand: gravel) by weight of cement. The addition of (Styrene- Butadiene - Rubber) SBR in the mix enlarged the compressive, splitting tensile and flexural strength. Lafta (2017) [8] developed lightweight concrete using plastic aggregate with varying percentages $25 \%, 50 \%$ and $75 \%$ for four mixtures (SBR) to gain higher strength.

This research focuses on recycling waste material and using it as a coarse aggregate such as plastics and reducing cement content in the concrete mix in order to produce sustainable concrete. Therefore, the studyis devoted to evaluate the effects of using waste plastic aggregate instead of natural aggregate on themechanical properties of resulting concrete.

\section{Experimental Program}

\subsection{Materials}

\subsubsection{Cement}

The used Type I cement properties are given in Tables 1 and 2 . They stratify to the Iraqi Specification No. 5 [9].

Table 1: Chemical testing of cement

\begin{tabular}{|l|c|c|}
\hline Oxide composition & Content & Limits of Iraqi Specification \\
& & No.5 [9]. \\
\hline
\end{tabular}




\begin{tabular}{|l|l|l|}
\hline $\mathbf{C a O}$ & 63.26 & - \\
\hline $\mathrm{SiO2}$ & 19.22 & - \\
\hline $\mathbf{A l}_{\mathbf{2}} \mathbf{O}_{\mathbf{3}}$ & 4.51 & - \\
\hline $\mathrm{Fe}_{\mathbf{2}} \mathbf{O}_{\mathbf{3}}$ & 3.34 & - \\
\hline $\mathbf{M g O}$ & 2.62 & $(5)$ maximum \\
\hline $\mathbf{S O 3}$ & 2.05 & $(2.8)$ maximum \\
\hline Loss on ignition & 2.40 & $(4)$ maximum \\
\hline Insoluble residue & 0.48 & $(1.5)$ maximum \\
\hline $\begin{array}{l}\text { Lime saturation } \\
\text { factor }\end{array}$ & 0.93 & $(0.66-1.02)$ \\
\hline $\mathbf{C}_{\mathbf{3}} \mathbf{S}$ & 70.60 & - \\
\hline $\mathbf{C}_{\mathbf{2}} \mathbf{S}$ & 2.30 & - \\
\hline $\mathbf{C}_{\mathbf{3}} \mathbf{A}$ & 6.30 & - \\
\hline $\mathbf{C}_{\mathbf{4}} \mathbf{A F}$ & 10.10 & - \\
\hline
\end{tabular}

Table 2: Physical testing of cement

\begin{tabular}{|l|l|l|}
\hline \multicolumn{1}{|c|}{ Physical properties } & $\begin{array}{c}\text { Test } \\
\text { result }\end{array}$ & $\begin{array}{c}\text { Limit of Iraqi } \\
\text { Specification No.5 [9] }\end{array}$ \\
\hline $\begin{array}{l}\text { Specific surface area (Blaine } \\
\text { method) } \mathbf{~ m}^{\mathbf{2}} \mathbf{k g}\end{array}$ & 350 & 230 (minimum) \\
\hline $\begin{array}{l}\text { Setting time (Yicale's method) } \\
\text { Initial setting, hrs.: min } \\
\text { Final setting, hrs.: min }\end{array}$ & $2: 33$ & $00: 45$ (min.) \\
\hline Compressive strength, MPa & $5: 25$ & $10: 00$ (max.) \\
3 days & 20.5 & 15.00 (minimum) \\
7 days & 26.5 & 23.00 (minimum) \\
\hline Autoclave expansion \% & 0.25 & 0.8 (maximum) \\
\hline
\end{tabular}

\subsubsection{Fine aggregate}

A $4.75 \mathrm{~mm}$ maximum size of sand having fineness modulus of (2.87) was used. The sand sieve analysis is shown in Table-3 which is relevant to the Iraqi Specification No. 45[10]. Table-4 shows the sand physical properties.

Table 3: Sieve analysis of fine aggregate

\begin{tabular}{|c|c|c|}
\hline $\begin{array}{l}\text { Sieve size } \\
(\mathbf{m m})\end{array}$ & $\begin{array}{c}\text { Passing } \\
\%\end{array}$ & $\begin{array}{l}\text { Limit of Iraqi Specification No. } 45 \text { for } \\
\text { zone } 2[10]\end{array}$ \\
\hline 10 & 100 & 100 \\
\hline 4.75 & 96 & $90-100$ \\
\hline 2.36 & 76 & $75-100$ \\
\hline 1.18 & 58 & $55-90$ \\
\hline 0.6 & 37 & $35-59$ \\
\hline 0.3 & 9 & $8-30$ \\
\hline 0.15 & 2 & $0-10$ \\
\hline
\end{tabular}

Table 4: Physical properties of fine aggregate.

\begin{tabular}{|c|c|c|}
\hline Properties & Test results & $\begin{array}{l}\text { Limit of Iraqi Specification No. } \\
45 / 1984[5]\end{array}$ \\
\hline $\mathrm{SO}_{3} \%$ & 0.35 & $\leq 0.5$ \\
\hline Specific gravity & 2.65 & --- \\
\hline Absorption \% & 1.8 & --- \\
\hline
\end{tabular}

\subsubsection{Coarse aggregate}

The maximum size of $(10 \mathrm{~mm})$ crushed gravelhaving specific gravity (2.64)was used in the concrete blends. The coarse aggregate sieve analysis is shown in Table 5 which is relevant to the Iraqi Specification No. 45 [10].

Table 5: Grading of coarse aggregate

\begin{tabular}{|c|c|c|}
\hline $\begin{array}{c}\text { Sieve size } \\
(\mathbf{m m})\end{array}$ & $\begin{array}{c}\text { Passing } \\
\mathbf{\%}\end{array}$ & $\begin{array}{c}\text { Limit of Iraqi Specification No. 45 } \\
{[\mathbf{1 0}]}\end{array}$ \\
\hline $\mathbf{1 2 . 5}$ & 100 & 100 \\
\hline $\mathbf{9 . 5}$ & 98.14 & $85-100$ \\
\hline $\mathbf{4 . 7 5}$ & 14.08 & $10-30$ \\
\hline $\mathbf{2 . 3 6}$ & 1.94 & $0-10$ \\
\hline $\mathbf{1 . 1 8}$ & 0.96 & $0-5$ \\
\hline
\end{tabular}

\subsubsection{Recycled coarse aggregate}

PVC plastic waste aggregate of size $10 \mathrm{~mm}$ and thickness of 1.5 $\mathrm{mm}$ is used as coarse aggregateas shown in figure (1). The specific gravity was (1.36)with $(0.0 \%)$ water absorption at (24 hr) and have bulk density $\left(800 \mathrm{~kg} / \mathrm{m}^{3}\right)$.

This type of aggregate cannot be used at higher temperatures because of the melting point of this plastic is low about $200 \mathrm{C}^{0}$. This type of thermoplastic plastic is from the polyolefin family. It is the polymer of the vinyl chloride monomer. The molecular formula of PVC plastic is $\left(\mathrm{C}_{2} \mathrm{H}_{2} \mathrm{Cl}\right)$. The grading of recycled coarse aggregate is shown in Table 6.

Table 6: Grading of recycled coarse aggregate

\begin{tabular}{|c|c|c|}
\hline Sieve size (mm) & $\begin{array}{c}\text { Passing } \\
\text { \% }\end{array}$ & $\begin{array}{c}\text { Limit of Iraqi Specification No. 45 } \\
{[\mathbf{1 0}]}\end{array}$ \\
\hline $\mathbf{1 2 . 5}$ & 100 & 100 \\
\hline $\mathbf{9 . 5}$ & 94.24 & $85-100$ \\
\hline $\mathbf{4 . 7 5}$ & 60.42 & $10-30$ \\
\hline $\mathbf{2 . 3 6}$ & 2.3 & $0-10$ \\
\hline
\end{tabular}

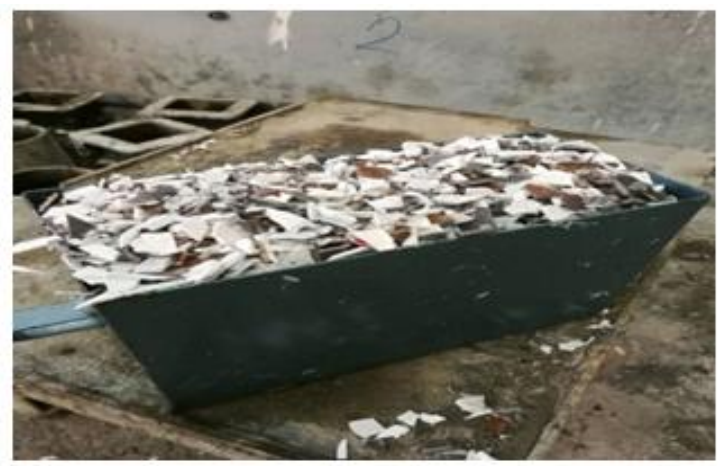

Fig. 1: PVC plastic.

\subsubsection{Super plasticizer}

The superplasticizer used in this work was PCE 600 which has been primarily developed for applications in the precast, light weight and aerated concrete industries.

PCE 600 is different than conventional superplasticizer based on sulfonated melamine and naphthalene formaldehayde condensate, which create electrostatic repulsion of particles. Table 7 indicates the technical description of the aqueous solution of the superplasticizer used throughout this work by weight of cement.

Table 7: Properties of superplasticizer[11].

\begin{tabular}{|l|l|l|}
\hline $\mathbf{1}$ & Properties & superplasticizer \\
\hline $\mathbf{2}$ & Appearance & Yellow liquid \\
\hline $\mathbf{3}$ & Specific gravity & 1.06 @ 20 $\mathrm{c}$ \\
\hline $\mathbf{4}$ & Air entrainment & $1 \%$ Maximum \\
\hline $\mathbf{5}$ & Chloride content & Zero \\
\hline $\mathbf{6}$ & Nitrate content & Zero \\
\hline
\end{tabular}

\subsubsection{Mineral Admixture (Silica Fume (SF)):}

The used silica fume satisfies the conditions required by ASTM C1240 [12]. The silica fume is used herein in order to reduce cement content and therefore producing sustainable concrete.

\subsubsection{Concrete mixtures}

Sixteentrial mixtures have been tested in order to study the effect of PVC waste aggregate on properties ofconcrete and to develop sustainable concrete. The blends requiredstrength in compression was (28MPa) for bothcrushed gravel concrete (NAC)and (RAC) plastic coarse aggregate concrete. The mix design suggested by ACI 211.1/1991 [13] is used to design the concretemixtures. The blends are shown in Table- 8 and Table- 9 . The water cement ratio $(\mathrm{w} / \mathrm{c})$ is varied in order to obtain workability in the mix.

Table 8: Mix proportion of RA concrete mixtures

\begin{tabular}{|c|c|c|c|c|c|c|c|}
\hline $\begin{array}{l}\mathbf{M} \\
\mathbf{i x} \\
\mathbf{N}\end{array}$ & $\begin{array}{c}\text { Cem } \\
\text { ent } \\
\text { cont }\end{array}$ & $\begin{array}{c}\text { San } \\
\text { d } \\
(\mathrm{kg} /\end{array}$ & $\begin{array}{c}\text { Gra } \\
\text { vel } \\
(\mathrm{kg} /\end{array}$ & $\begin{array}{c}\% \\
\text { Replace } \\
\text { ment of }\end{array}$ & $\begin{array}{c}\% \\
\text { Superplast } \\
\text { isizer. by }\end{array}$ & $\begin{array}{l}\text { \% Silica } \\
\text { Replace } \\
\text { ment of }\end{array}$ & $\begin{array}{c}\text { W/ } \\
\text { C }\end{array}$ \\
\hline
\end{tabular}




\begin{tabular}{|c|c|c|c|c|c|c|c|}
\hline 0. & $\begin{array}{c}\text { ent } \\
(\mathrm{kg} / \\
\left.\mathrm{m}^{3}\right)\end{array}$ & $\left.\mathrm{m}^{3}\right)$ & $\left.\mathrm{m}^{3}\right)$ & gravel & $\begin{array}{c}\text { wt. of } \\
\text { cement }\end{array}$ & cement & \\
\hline $\begin{array}{c}\mathrm{R} \\
1\end{array}$ & 525 & 626 & 945 & 100 & 1.5 & 15 & $\begin{array}{c}0.2 \\
4\end{array}$ \\
\hline $\begin{array}{c}\mathrm{R} \\
2\end{array}$ & 460 & 625 & 945 & 25 & 2.3 & 15 & $\begin{array}{c}0.3 \\
4\end{array}$ \\
\hline $\begin{array}{c}\mathrm{R} \\
3\end{array}$ & 460 & 625 & 945 & 50 & 2 & 15 & $\begin{array}{c}0.3 \\
4\end{array}$ \\
\hline $\begin{array}{c}\mathrm{R} \\
4\end{array}$ & 460 & 625 & 945 & 75 & 2 & 15 & $\begin{array}{c}0.3 \\
4\end{array}$ \\
\hline $\begin{array}{c}\mathrm{R} \\
6\end{array}$ & 460 & 625 & 945 & 100 & 2 & 15 & $\begin{array}{c}0.3 \\
4\end{array}$ \\
\hline $\begin{array}{c}\mathrm{R} \\
6\end{array}$ & 400 & 625 & 945 & 100 & 2 & 15 & $\begin{array}{c}0.3 \\
4\end{array}$ \\
\hline $\begin{array}{c}\mathrm{R} \\
7\end{array}$ & 375 & 637. & 1125 & 100 & 2 & 15 & 0.3 \\
1
\end{tabular}

*where $(\mathrm{R})$ mean recycled aggregate.

Table 9: Mix proportion of NA concrete mixtures

\begin{tabular}{|c|c|c|c|c|c|c|}
\hline $\begin{array}{c}\text { Mi } \\
\mathbf{x} \\
\text { No } \\
\text {. }\end{array}$ & $\begin{array}{c}\text { Ceme } \\
\text { nt } \\
\text { conte } \\
\text { nt } \\
\left(\mathrm{kg} / \mathrm{m}^{3}\right. \\
)\end{array}$ & $\begin{array}{c}\text { Sand } \\
(\mathrm{kg} / \mathrm{m} \\
3)\end{array}$ & $\begin{array}{c}\text { Grav } \\
\text { el } \\
(\mathrm{kg} / \mathrm{m} \\
3 \\
)\end{array}$ & $\begin{array}{c}\% \\
\text { Superplastisiz } \\
\text { er. by wt. of } \\
\text { cement }\end{array}$ & $\begin{array}{c}\text { \% Silica } \\
\text { Replaceme } \\
\text { nt of } \\
\text { cement }\end{array}$ & $\begin{array}{l}\text { W/ } \\
\text { C }\end{array}$ \\
\hline N1 & 400 & 700 & 1100 & 0 & 0 & $\begin{array}{c}0.4 \\
5\end{array}$ \\
\hline N2 & 525 & 625 & 945 & 0 & 0 & $\begin{array}{c}0.4 \\
1\end{array}$ \\
\hline N3 & 525 & $\begin{array}{c}624.7 \\
5\end{array}$ & 945 & 1.5 & 15 & $\begin{array}{c}0.2 \\
3\end{array}$ \\
\hline N4 & 525 & 625 & 945 & 1.5 & 15 & $\begin{array}{c}0.2 \\
3\end{array}$ \\
\hline N5 & 525 & 625 & 945 & 2.3 & 15 & $\begin{array}{c}0.2 \\
4\end{array}$ \\
\hline N6 & 300 & 600 & 1200 & 2 & 15 & $\begin{array}{c}0.3 \\
3\end{array}$ \\
\hline N7 & 250 & 725 & 1100 & 2 & 15 & 0.3 \\
\hline N8 & 275 & 800 & 1000 & 2 & 15 & $\begin{array}{c}0.3 \\
6\end{array}$ \\
\hline N9 & 275 & 700 & 1000 & 2 & 15 & $\begin{array}{c}0.3 \\
6\end{array}$ \\
\hline
\end{tabular}

*where $(\mathrm{N})$ means natural aggregate.

\subsection{Mechanical Properties of Concrete}

\subsubsection{Workability (Slump Test)}

The workability of blends was measured immediately after blendsof concrete constitutes in accordance with test method of ASTM C143 [14]. The w/c ratio for high strength concrete mixture was adjusted to have thesame workability (slump of $95 \pm$ $5 \mathrm{~mm}$ ) as shown in table (9) and figure (2).

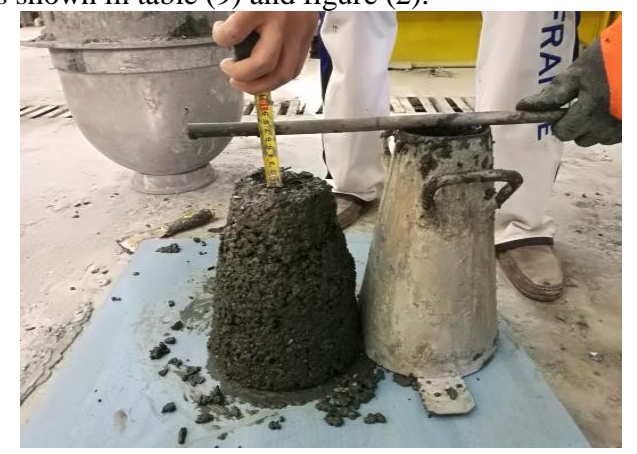

Fig. 2: Slump test

\subsubsection{Fresh Density Test}

The concrete fresh density for all blends was calculated immediately after blending concrete (ASTM C 138M-01) [15]. It was determined using the following equation:
$\gamma_{f}=\left(\mathrm{W}_{\mathrm{c}}-\mathrm{W}_{\mathrm{m}}\right) / \mathrm{V}_{\mathrm{m}}$

where:

$\gamma_{f}$ is the fresh concrete density $\left(\mathrm{kg} / \mathrm{m}^{3}\right)$.

$\mathrm{W}_{\mathrm{c}}$ is the weight of mold contains concrete blends $(\mathrm{kg})$.

$\mathrm{W}_{\mathrm{m}}$ is the weight of empty mold $(\mathrm{kg})$.

$V_{m}$ is the volume of the mold $\left(\mathrm{m}^{3}\right)$.

The result show that density decrease with increasing percentage of replacement to $100 \%$ and turn the mixture to light weight aggregate concrete mixas shown in table 9 .

Table 9: Fresh density and slump

\begin{tabular}{|c|c|c|}
\multicolumn{3}{|c}{ Table 9: Fresh density and slump } \\
\hline Mix No. & Fresh density $\left(\mathbf{k g} / \mathbf{m}^{\mathbf{3}}\right)$ & Slump $\mathbf{( m m})$ \\
\hline R1 & 2116 & - \\
\hline R2 & 2314 & 85 \\
\hline R3 & 2210 & 90 \\
\hline R4 & 2086 & 98 \\
\hline R5 & 1992 & - \\
\hline R6 & 1950 & 100 \\
\hline R7 & 1871 & 60 \\
\hline N5 & 2452 & 100 \\
\hline N6 & 2385 & 60 \\
\hline N7 & 2430 & 60 \\
\hline N8 & 2433 & 190 \\
\hline N9 & 2485 & 60 \\
\hline
\end{tabular}

\subsubsection{Cube Compressive Strength}

The universal testing machine is used for testing samples in compressionwhich relevant to BS1881-116, 1997 [16] for cubes $\left(f_{c u}\right) 100 \mathrm{~mm} \times 100 \mathrm{~mm} \times 100 \mathrm{~mm}$ as shown in figure (3). Testing was carried out at 28 days;three cubes were tested at each time.Table 10 reveals the results of tests on concrete cubes under compression. It is obvious that the compressive strength of LWA concrete will be lesser when plastic aggregate percentage increases. In case of $100 \%$ plastic aggregate was used, the compressive strengths of concrete will be lesser by about $17 \%$ (difference between mix N5 and R1). The reason for reducing concrete strength devoted to the properties of waste aggregate and waste constitutes. According to ACI 318/2014 [17] all recycled aggregate concrete mixes can be used for producing structural concrete.
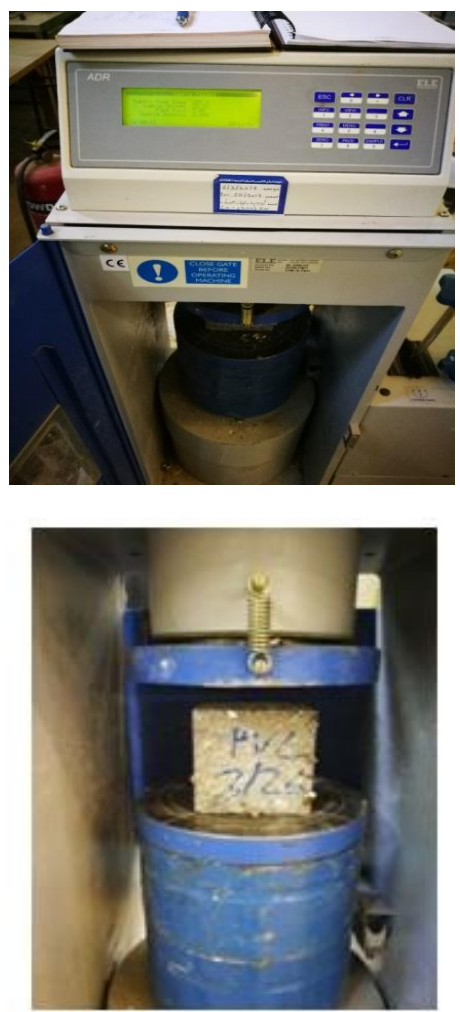

Fig. 3: Compression test 


\subsubsection{Splitting tensile strength}

This test wasmade on specimens which relevant to ASTMC496/ 2006 [18]. The testsamples were three $(100 \times 200 \mathrm{~mm})$ cylinders and tested as shown in figure (4).The test results (the average of three samples)are shown in Table-10. It is obvious that the tensile strength have lower values as plastic or recycled aggregate percentageenlarged. The reason for reducing tensile concrete strength is devoted to the properties of waste aggregate and waste constitutes. The natural aggregate are stronger than waste aggregate in resisting tensile stresses. The ACI 318/2014 [17] split cylinder strength equation $\left(\mathbf{f}_{\mathbf{c t}}=\mathbf{0 . 5 6} \sqrt{\mathbf{f}^{\prime}} \mathbf{c}\right)$ underestimate the value of tensile strength for natural or normal aggregate concrete and recycled or waste aggregate.
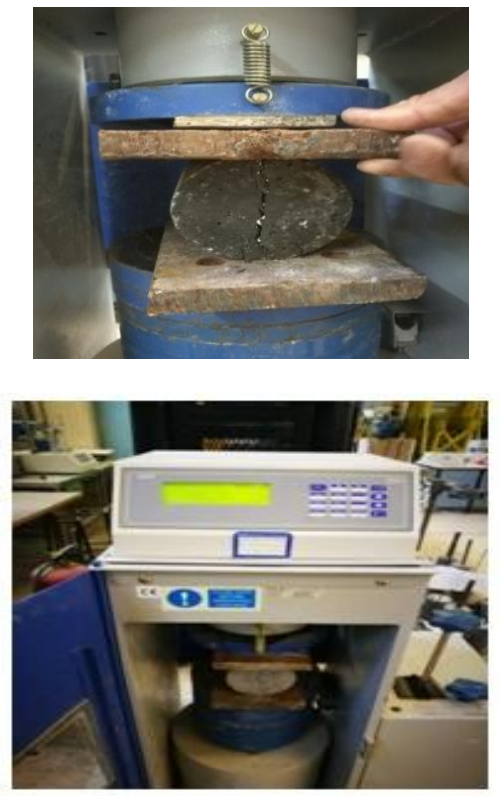

Fig. 4: Splitting tensile test

Table 10: Cube compressive and splitting tensile strength result

\begin{tabular}{|c|c|c|c|c|}
\hline $\begin{array}{l}\text { Mix } \\
\text { No }\end{array}$ & $\begin{array}{l}\text { Cube } \\
\text { compressive } \\
\text { strength (MPa) } \\
\text { @ 28days }\end{array}$ & $\begin{array}{l}\text { Tensile } \\
\text { Strength } \\
\text { (MPa)@ - } \\
\text { 28days }\end{array}$ & $\begin{array}{l}\text { ACI } \\
318 / 2014[17] \\
\text { Tensile } \\
\text { Strength } \\
\text { Equation } \\
\mathrm{f}_{\mathrm{ct}}=0.56 \sqrt{ } \mathrm{f}^{\prime} \mathrm{c}\end{array}$ & 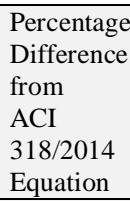 \\
\hline N1 & 24.8 & - & 2.78 & - \\
\hline N2 & 33.2 & - & 3.23 & - \\
\hline N3 & 32.2 & - & 3.18 & - \\
\hline N4 & 37.7 & - & 3.43 & - \\
\hline N5 & 64.6 & 3.84 & 4.5 & -14.66 \\
\hline N6 & 32.7 & 2.68 & 3.2 & -16.25 \\
\hline N7 & 26 & 1.88 & 2.86 & -34.26 \\
\hline N8 & 34.5 & 2.205 & 2.29 & -3.71 \\
\hline N9 & 37.6 & 2.36 & 3.43 & -31.19 \\
\hline R1 & 53.7 & 2.95 & 4.1 & -28.05 \\
\hline $\mathbf{R 2}$ & 50.2 & 2.66 & 3.97 & -33.0 \\
\hline R3 & 40.2 & 2.52 & 3.55 & -29 \\
\hline R4 & 44.5 & 2.44 & 3.736 & -34.7 \\
\hline R5 & 33.3 & 2.55 & 3.23 & -21.05 \\
\hline R6 & 34.9 & 1.74 & 3.31 & -47.4 \\
\hline R7 & 22.5 & 1.61 & 2.65 & -39.2 \\
\hline
\end{tabular}

\section{Conclusions}

The following study conclusionsare obtained in the present work: The concrete tensile and compressive strengths varied in values whichrelated on the plastic aggregate replacement ratio.This may be discarded for ratio lower than $25 \%$. For higher replacement ratio, the mechanical properties are lowered with enlarging plastic aggregate content. It is preferred to use replacement ratio of $25 \%$
All studied concrete blends are considered as structural concrete according to ACI $318 / 2014$.

The equation developed by ACI 318/2014 for obtaining split tensile strength equation is giving lower value than experimental one for normal aggregate concrete. For concrete blends having plastic aggregate content higher than $50 \%$, it is not recommended to use the ACI equation.

The density of concrete decrease with increasing the percentage of PVC plastic replacement.

PVC plastic aggregate require less water in the blends than natural aggregate.

\section{References}

[1] Saikia, N., and De Brito, J., "Use of Some Solid Waste Material asAggregate, Filler or Fiber in Cement Mortar and Concrete", Advances inMaterial Science Research, Vol. 3, pp.65-116, 2011.

[2] Siddique, R., Khatib, J., and Kaur, I., "Use of Recycled Plastic inConcrete: a Review", International Journal of Civil, Structural,Environmental and Infrastructure Engineering Research andDevelopment, Vol. 3, No.2, pp. 9-16, 2013.

[3] Damtoft, J. S., "Use of Fly Ash and Other Waste Materials as Raw Feed and Energy Source in the Danish Cement Industry", proceedings ofCANMET/ACI, International symposium on Sustainable Developmentof the cement and concrete industry, Canada, Oct. 1998

[4] Elzafraney M., Soroushian P., and Deru, M. "Development of energy-efficient concrete buildings using recycled plastic aggregates ". Journal of Architectural Engineering, Vol. 11, No 4, 2005, pp.122-130.

[5] Jasim K. I., "Reuse of waste plastic as hollow shape aggregate in lightweight concrete", M. Sc. Thesis, Environmental Engineering, College of Engineering, University of Baghdad, 2009.

[6] Mathew P., Varghese S., and Paul T., "Recycled plastics as coarse aggregate for structural concrete" International Journal of Innovative Research in Science, Engineering and Technology Vol. 2, Issue 3, March 2013.

[7] Khalaf K. J., "Studying the utilization of polymeric wastes to produce sustainable concrete", M.Sc. Thesis, Building and Construction Engineering Department, University of Technology, 2015

[8] Lafta J. A., " The production of high strength concrete slabs using plastic as an alternative" Babylon university journal for engineering science, Vol. 25, No 3, 2017

[9] Iraqi specification No.5/1984. Portland cement. Central Agency for Standardization and Quality Control, Planning Council, Baghdad, Iraq.

[10] Iraqi specification No. 45/1984. Aggregate from Natural Sources for Concrete", Central Agency for Standardization and Quality Control, Planning Council, Baghdad, Iraq.

[11] ASTM C 494-05, "Standard Specification for Chemical Admixtures for Concrete", Manual Book of ASTM Standards, Vol.04.02, 2005, pp. $248-255$.

[12] ASTM C 1240, "Standard Specification for Silica Fume Used in Cementitious Mixtures", American Society for Testing and Material, 2005,183 pp.

[13] ACI 211.1. Standard Practice for Selecting Proportions for Normal, Heavyweight and Mass Concrete. American Concrete Institute: 638.1991

[14] ASTM C143M, "Standard Test Method for Slump of HydraulicCement Concrete", American Society for Testing and Materials, Vol.04.02, pp.1-4, 2007.

[15] ASTM C138M, "Standard Test Method for Unit Weight, Yield, andAir Content (Gravimetric) of Concrete ", Annual Book of ASTMStandards, American Society for Testing and Materials, Vol. 04.02, pp.1-3, 2005.

[16] BS1881-116. Method for Determination of Compressive Strength of Concrete Cubes. British Standards Institute, London, 1997.

[17] ACI318-14. Building Code Requirements for Structural Concrete and Commentary, American Concrete Institute, Detroit, U.S.A,2014.

[18] American Society for Testing and Materials. Standard Method of Test for Splitting Tensile, 2006. 